\title{
Patients age: so does wine
}

\author{
Shaun R. McCann ${ }^{1}$
}

Received: 14 February 2019 / Revised: 15 February 2019 / Accepted: 15 February 2019 / Published online: 26 February 2019

(c) Springer Nature Limited 2019

Age is just a number, it is totally irrelevant, unless, of course, you happen to be a bottle of wine.

Dame Joan Collins. DBE. English actress. 1933-

As doctors we all know that people seem to age at different rates. One person in his/her 60s looks older than a sprightly person in their late 70s. As haematologists we thought that the prognosis in patients with acute myeloid leukaemia (AML) and acute lymphocytic leukaemia (ALL) was age dependent. This was largely explained by comorbidity in adults with these diseases. We now know that there are other factors involved. It turns out that there are different cytogenetic and molecular abnormalities, including clonal haematopoiesis $(\mathrm{CH})$, in older patients with AML which renders their disease relatively resistant to standard chemotherapy. Of course if you consider haematopoietic cell transplantation (HCT), then we have known that older patients tolerate so-called myeloablative conditioning poorly, hence the development of reduced intensity conditioning (RIC). Although RIC is tolerated better than myeloablative conditioning we may have increased the risk of leukaemic relapse.

In adult patients with ALL we now know that the prevalence of the Philadelphia chromosome, $t$ (9:22), increases with age and this probably accounts for the poorer prognosis in older adults. Not only does the presence of the Philadelphia chromosome increase with age but age stratification studies show that the older the patient cohort, the higher the prevalence of the $t$ (9:22) translocation and this may reach $50 \%$ of cases. Of course the use of tyrosine kinase inhibitors (TKIs) in the treatment of adults with ALL and the $t(9: 22)$ has completely altered the landscape.

Shaun R. McCann

shaunrmccann@gmail.com

1 Professor Emeritus of Haematology and Academic Medicine, St James' Hospital and Trinity College Dublin, Dublin, Ireland
A bottle of Château Petrus

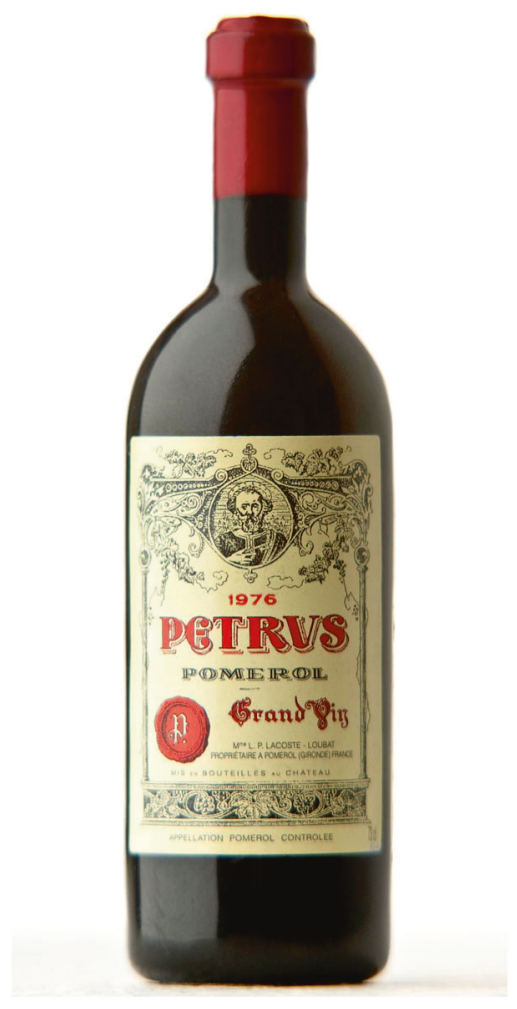

A recent article from Japan [1] by Espinoza and colleagues again restates the putative benefits of resveratrol [2] and the possibility that wine consumption offers some protection from haematological malignancies, perhaps based on its ability to inactivate viruses.

What about ageing in wine? Our old friend Galen wrote, among many other things, that wine consumption, in moderation, was good for one's health. Apparently when he was physician in Pergamum he recommended it as part of the daily rations for gladiators and history records that not a single gladiator died when Galen was in charge! Wine also served as an antiseptic for wounds and an analgesic for surgery. When he became physician to Emperor Marcus Aurelius, he developed pharmaceutical 
concoctions made from wine known as 'theriacs' which were believed to protect against poisons and cure everything from the plague to mouth sores. This idea lasted until the 18 th century.

Everybody is probably familiar with ageing in red wines. A number of factors are required to facilitate the ageing process: the wine must be capable of ageing and must be correctly stored. According to Halliday and Johnson in their book: 'The art and science of wine' [3] the main process of ageing depends on the interaction between oxygen, tannins and anthrocyanins although they say that ageing may still take place in the absence of oxygen but at a slower rate. Red wines change from the vivid purple of youth to the brick red of old age. The other important change with ageing is esterification. Oxygen interacts with acids and alcohol to form esters and aldehydes. How much this contributes to the bouquet of aged wines is a matter of opinion. In the old days when 'big' houses had wine cellars and substantial wine collections, fine wines were made for ageing. Prominent wine makers, usually from Bordeaux and Burgundy, would send their man (it was always a man) to the 'big' houses to top up and re-cork the fine wines. Now most wines can be consumed within 2-3 years of bottling.

Ageing, however, is not confined to red wines. Robinson writing in the weekend FT [4] in January blames the denigration of ageing white wine to the American wine guru Robert Parker. She says: 'white wines tend to be more refreshing and are far less likely to be oaky, full-bodied and chewily tannic'. Her recommendation for white wines for ageing include Chablis, Sauterne, Fiano di Avellino, Soave, Riesling, Tokaj and Hunter Valley Semillon.

However returning to aged Bordeaux such as Château Petrus (Pomerol, Merlot), the vines are only replanted after they reach 70 years of age. The grapes are hand harvested in the afternoon, when the morning dew has evaporated, so as not to risk even the slightest dilution of quality. The grapes are fermented in cement vats and the wine is aged in $100 \%$ new oak barrels for 22-28 months. It is bottled unfiltered. If you have a 30 year old bottle of Ch Petrus, kept in pristine conditions, it should fetch from $\$ 10,000-\$ 15,000$ per bottle. On the other hand you could drink it!

Happily as a humble haematologist (is that an oxymoron?) I don't have such decisions to make!
Statue of Dionysus (Roman Bacchus) on the Ponte Santa Trinità in Florence, Italy. Courtesy of Brenda Moore-McCann

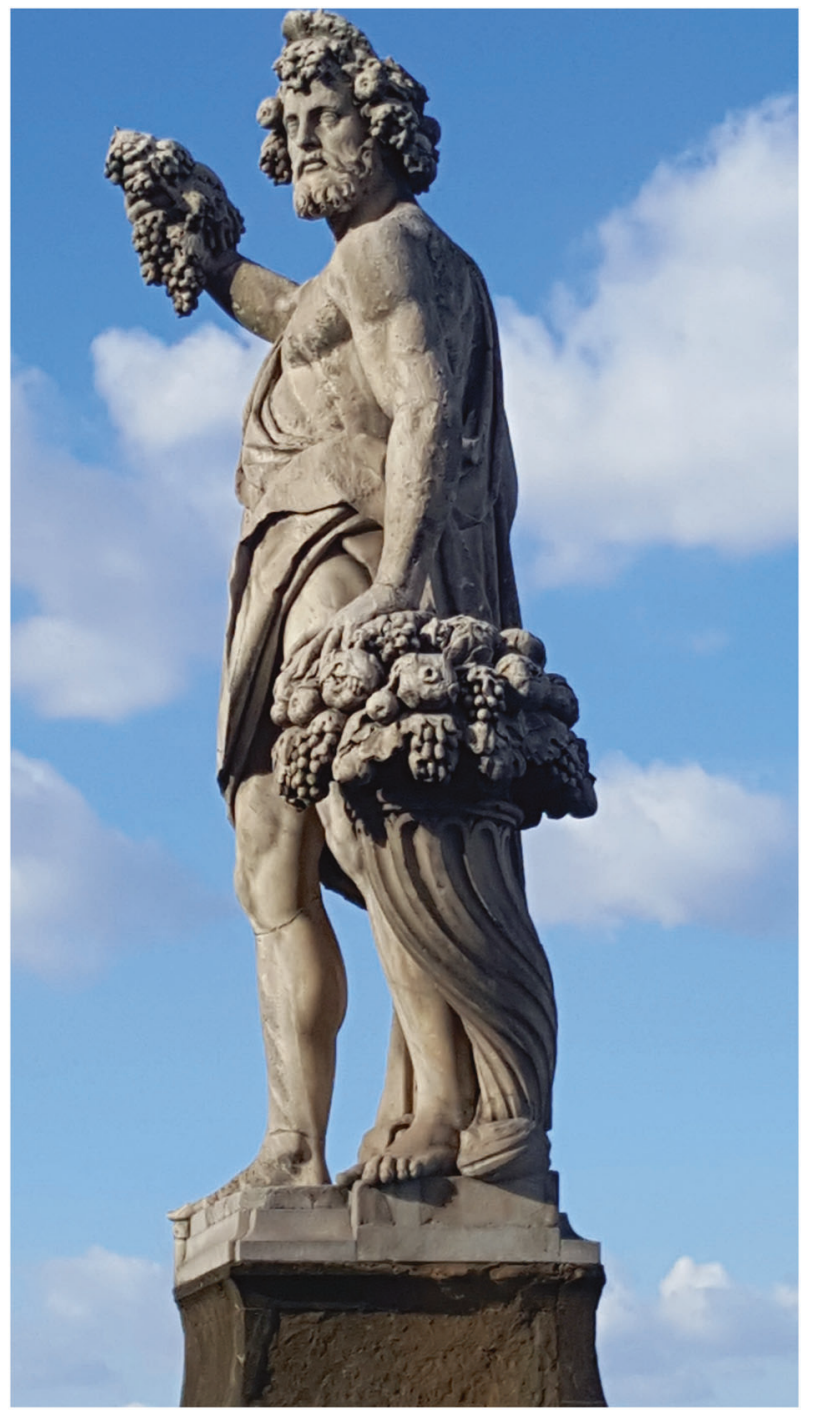

Acknowledgements I am grateful to Hillard Lazarus for bringing the paper by Espinoza and colleagues to my attention.

\section{Compliance with ethical standards}

Conflict of interest The author declares that he has no conflict of interest.

Publisher's note: Springer Nature remains neutral with regard to jurisdictional claims in published maps and institutional affiliations. 


\section{References}

1. Espinoza JL, Yu K, Takami A. Rationale for assessing the therapeutic potential of resveratrol in hematological malignancies. 2019. Blood Rev. 2019;33:43-52. https://doi.org/10.1016/j.blre. 2018.07.001.
2. McCann S. Antioxidants: good, bad or indifferent. Bone Marrow Transplant. 2018, https://doi:org/10.1038/s409-018-0397-9.

3. Halliday J, Johnson $\mathrm{H}$. The art and science of wine; Mitchell Beazley, an imprint of the Octopus Publishing Group Ltd., London, U.K. 1992.

4. Robinson J. Wine. The great whites. FT weekend, $5 / 6^{\text {th }}$ January 2019. 